\title{
3. Speech, Children and the Federation Movement
}

\section{Alan Atkinson}

It is still something of a mystery as to why voters in Australia agreed to the federation of the colonies in 1901. The prevailing argument among historians for many years made much of regional economic interests, but during the 1990s a new type of Australian nationalism led to a focus on motivation of a more altruistic kind. The inspirational language used by men such as Edmund Barton and Alfred Deakin, by patriotic writers of fiction and verse and by oratorically gifted members of the Australian Natives Association (ANA), during the 1880s and 1890s, has been dissected for what it says about genuine feelings of Australian nationhood. John Hirst has argued that Federation was due to a real and widespread sense of shared territory - a land 'girt by sea' — and of common destiny. ${ }^{1}$ Bob Birrell has likewise written in convincing detail about a large program of innovative and high-minded social reform, which he says was sketched out before 1901 by leading writers and activists and largely carried through thereafter, in the years before World War I.

Birrell's contribution is especially interesting for present purposes because he describes Federation not only as a business of sentiment (which is Hirst's main idea), but as a scheme of ideas, a challenge to contemporary imagination. He describes the proselytising work of the ANA, for instance, as an exercise in cultural self-improvement for members and for those who fell under their influence. Feelings of national involvement were understood by the ANA to be an inevitable result of better knowledge - of a deeper and wider comprehension of Australian circumstances. ${ }^{2}$ I am not aiming here to argue around the point as to why Australians voted as they did. Only during the 1890s was there much widespread popular enthusiasm for Federation-leading to the successful referenda of 1899-1900 - and the material I am using relates mainly to the 1870s and 1880s. I do want to make use of the idea that Federation was an effort largely of intellect and imagination - if I can use those words without suggesting that effort was justified in every detail. Benedict Anderson talks about nationalism as an ideology that depends on the existence, for each citizen, of an imagined community' to which he or she seems to belong. The imagining of that community I take to be an intellectual process, perfectly abstract and even counter-intuitive. It might be imbibed by adult reading - of newspapers in particular-but also, of course, it depends on what happens in schools.

The older approach to the federation movement, focusing solely on economic self-interest, seems now to have been partly discredited, but in one respect, 
perhaps, it was more firmly based than the current orthodoxy. It has become common practice since the 1990s to talk about Federation just as Americans think about the revolution of 1775-83. It is understood to be an event bearing immediately on us as a matter of national and individual identity. It therefore seems pivotal, even providential, within long-term Australian experience. Previously, Federation was used by historians like any ordinarily complex event - mainly as a fund of evidence about the circumstances of the time. It was a means of commenting, for instance, on the early evolution of the labour movement or on the vicissitudes of free trade. It was treated much as we might treat, say, the rebellion in Sydney in 1808 against Governor Bligh, which had a continuing significance mainly as the source of well-documented argument about contemporary ideas and relationships. This is the approach I want to take to the federation movement, or rather to its early stages. Federation can be understood as the result of a particular cast of thought, a particular way of envisaging the world, which-instead of prefiguring current national and individual identity - was alien to the way we think now.

During the second half of the nineteenth century, in every one of the Australian colonies, the elementary school system - the system designed to cater for the mass of the population up to the age of 12 or 14-was reformed fundamentally. The changes imposed on teachers, parents and children were meant to meet two needs. In the first place, schools had to be provided for populations that were much larger and more scattered than they had been before the 1850s. Secondly, there were new ideas about the whole teaching process, which affected Australia as part of the British Empire and the European world. Schools were designed to create universal literacy and a mass culture for the nation-state. In addition, the 'art of teaching' - the way in which teachers were meant to behave in the classroom, and beyond - was largely altered.

The pedagogical reforms of that period have not been much examined by educational historians, at least compared with those of the early 1800s and the very end of the century. The federation movement has to be understood, however, in the context of orthodoxies prevailing in the 1870s and 1880 s - methods and approaches that made their way into the schools, to great acclaim, mainly during the late 1860s and early 1870s. Under this regime, teachers made a self-conscious effort to improve on their predecessors. They tried to do more than impart knowledge: they also aimed to encourage independent reasoning. They were aware that children's minds developed in complicated ways and they understood that certain types of ideas matched certain stages of growth. Their purpose was 'the training of mental powers'. They tried to shape the thinking process, but also the training of mental powers was to be manifest in tangible ways. In theory, good teaching involved the child as a physical and intellectual being. Teachers, as an Australian school inspector said at the time, 
must 'train the eye to see, the ear to hear, and the hands to execute what the mind conceives and wills'. 3

We are familiar today with pedagogical theory stressing individual and independent expression. This was not then a high priority. Expression was certainly important, but it was expected to show the obvious imprint of cultural authority. The basic subjects of the elementary curriculum were reading, writing and arithmetic. Reading was always listed first, and reading and writing were understood to be quite separate processes. In earlier generations, many children, especially girls, had never progressed beyond reading, and had never mastered either writing or arithmetic. Recent reforms were meant to give everyone a basic competence in all three and yet reading remained pre-eminent. 'No subject in our elementary school course,' said Thomas Burgan, a South Australian inspector of schools, in 1877, 'is perhaps more important than reading. ${ }^{4}$ All the evidence suggests that this was the common understanding. Besides the three Rs, a range of other subjects was available - at least in the bigger schools and to older children. Of these, as I say later, the most widely and effectively taught was geography, at least until about 1890 when, for reasons I will not explore here, it rapidly fell away. The mass teaching of geography was deeply characteristic of the period. It was also basic, as I will suggest, to the 'imagined community' of the nation.

Most of the detail below comes from the school inspectors' reports for the three leading Australian colonies from 1870 to 1890: New South Wales, Victoria and South Australia. I say 'leading' because in all three there was a cultural self-sufficiency, an independent sense of direction not to be found in Tasmania, Queensland or Western Australia. Inspectors had to give an annual account of the schools within their districts, comparing results from year to year, commenting on the physical condition of schools, equipment and furniture, the competence of teachers and the general behaviour of children. They commented also, if they saw fit, on the curriculum and on teaching methods used from place to place.

The length of the reports varied, but each might extend to several closely printed pages and all were published as part of the minister's annual report and bound with respective parliamentary papers. Part of each report was normally taken up with statistics, but generally the style was vivid and direct, and sometimes ironical, even whimsical, as inspectors struggled to reconcile the high aims of the school system with the realities they confronted from day to day. The contrast between official policy and humble experience runs parallel with the contrast I am trying to draw between imagined nationhood and what a Victorian inspector called 'the violent, boisterous talking-machine' to be found in many colonial schoolhouses. ${ }^{5}$ The two realities can be seen face to face on a country road in Victoria's Gippsland in 1884, when Thomas Hepburn, the district inspector, met 
a weeping four-year-old as they both made their way towards a school up that day for judgement. 'On inquiring the cause of distress,' said Hepburn, 'I received the following answer, choked with sobs, "Oh! I don't want to go to school to-day, the insect is coming."

During the third quarter of the nineteenth century, the incidence of literacy (that is, the ability to read and write) increased to something like 90 per cent within each colonial population. At first sight, then, this was very much a literate culture, but there was something narrowly instrumental, as we would see it, about contemporary attitudes to literacy. It is clear from the evidence of the inspectors' reports that reading and writing were valued mainly as aspects of speech. They were contingent, in other words, on another medium. It is hard to find in the reports much reference at all to reading purely for its own sake. It was understood that books were rarely part of common life among the mass of the population; not many were to be found in the homes of the poor. Many idealists hoped that books would soon be everywhere and certainly the number available had increased vastly during the previous two or three generations. There was still no sense, however, that children might, through their reading, make for themselves a discreet world of knowledge and imagination, a kind of visionary alternative to the palpable world around them. The abstract information and ideas offered in books were valued as mental training. They prepared the way for respectability in this world and, perhaps, salvation in the next. They made men and women useful - to themselves and to others. They were a means of civilisation, but they were always merely a means. Books, and the material they contained, were rarely an end in themselves.

Some idea of the way in which reading was contingent on sound can be seen in the suggestion of one inspector that children should be persuaded that 'in reading they are actually listening to wise and intelligent men and women they have never seen'. ${ }^{7}$ They were to do this mainly by reading out loud or, in other words, by listening to themselves. Reading out loud was the usual method of reading - or so it appears from the inspectors' reports. It was valued most highly at the elementary level - the level appropriate to the majority of the population - as a means of giving power and clarity to the voices of the children themselves. This was a very old idea. A seventeenth-century English pedagogue explained that children must learn about their own language, 'that they may be able in a gentle manner to converse with all sort of persons' ('gentle' can be taken to mean 'polite'). This early modern writer encouraged especially a concentration on words with 'a fair and ear-pleasing sound'. ${ }^{8}$ The intimate link between reading and speaking was obvious still in late-nineteenth-century Australia. When John Kevin, inspector at Bega in New South Wales, wrote that 'the children in our schools... [are] not taught to read at all', he meant, with some exaggeration, that they were not taught to read well out loud. They knew their 
letters, but that was not enough. It was all a question of 'intonation and inflection of voice', and that, he said, must be 'natural, intelligent, and pleasing'. ${ }^{9}$

While the idea was old, however, the method was self-consciously innovative. Writing in 1871, James McCredie, inspector at Bathurst in New South Wales, remarked that in most schools in his district reading was still taught in outmoded ways:

the names of the letters being mechanically dunned into the young child's mind, while nothing is said about the powers of the characters, and that they are mere marks to represent certain sounds. The pupil's interest is neither excited, nor is his intelligence cultivated by the irrational absurd method in question, and he is left to grope his way by dint of memory into a knowledge of the pronunciation of words, which he is made laboriously to spell over letter by letter before he names them.

This 'foolish custom', McCredie said, did more harm than good because it was hard afterwards for the child to understand that 'spelling and naming' were two very different things. It was naming - recognising words as a whole and saying them out loud - that was the first step of any importance in reading. ${ }^{10} \mathrm{~J}$. S. Jones of Armidale, New South Wales, made the same complaint at the same early stage: 'Few teachers in my district employ a judicious combination of the phonic and the look-and-say principles of teaching reading. Most of them adopt the alphabetic or spelling method, which is not only contrary to common sense, but is also uninteresting, tiring, and uncertain, to both pupil and teacher. ${ }^{11}$

Parents were part of the problem, at least in South Australia, where they seem to have had unusual influence. They 'naturally cling', it was said, 'to the method of their early days, by which years were sometimes devoted to what was known as the $\mathrm{A}, \mathrm{B}, \mathrm{C}^{\prime}$. $^{12}$

Educational historians have made too little of the complicated importance of speech for educational methods in this period. It jars a little with the common belief that late-nineteenth-century children were prepared partly for a world of silent reading and partly to be the passive employees of industry. In fact, the importance of speech training was stressed as a means of building up a truly democratic people. Charles Henry Pearson, in his report on the Victorian school system in 1878, spoke of the need to follow the example of the United States. There, he said, in the schools, '[m]ere children are taught to speak out so that they may be heard by a large number in a large room'. As a result, among adults in public meetings, 'the general fluency of comparatively untried speakers' was far beyond the normal standard in Britain and its colonies. ${ }^{13}$ A Victorian inspector echoed this idea in 1882. 'In a community like ours,' he said, 'where one may be called upon at any time to speak before his fellow-men, it is an immense advantage for a young man to have early become accustomed to the 
sound of his own voice.' Once again, the United States - 'a nation of ready public speakers' - ought to be the model. ${ }^{14}$

The matter went deeper than this: the kind of speech encouraged in schools was not only individual, it was communal. A good deal of class time was taken up with what was called 'simultaneous recitation': the chanting of lessons. It is easy today to think of this method of teaching as proof of a failure of effort and imagination among teachers. It was indeed justified partly as a means of keeping children occupied and their minds alert, but it was also part of the reforming program. 'A marked defect in the schools,' said J. S. Jones in 1871, 'is the almost entire absence of recitations.' By speaking and listening together, by taking advantage of what a leading British reformer had called the sympathy of numbers', children learnt to adapt their voices to the ideal. Simultaneous recitation was a means of induction into a uniform system of speech. Educational historians have featured the individual and competitive spirit, which was certainly part of educational practice in this period. ${ }^{15}$ on the other hand, however, schools - like nations - were meant to be communities. They were meant to be established on a foundation of sameness. That sameness was manifest partly in voices - a point I will come back to at the end of this chapter.

I now turn to geography - the teaching of which, surprisingly perhaps, helps to explain the importance of voices in the schools. Geography was a discipline of enormous interest to this generation. New methods of printing-first implemented in the 1830s-meant that maps were now much more easily available than they had been before. ${ }^{16}$ They began to appear in textbooks, although for most of our period it was usual for teachers to rely instead on large sheet maps hung up or draped over furniture. Children did not usually have maps of their own. In spite of being fairly common, then, maps were still at least slightly mysterious.

Cartographic literacy - associating space on a map with space in the real world - was and is a skill in its own right. It was a peculiarly fascinating skill at this time. It had obvious practical uses but also, like literacy proper, it seemed to be the key to other worlds. Unlike literacy proper, it led inevitably to silent rather than spoken imaginings. Flora Thompson, who had been an English schoolgirl in this period, recalled the maps hung about her classroom. 'During long waits for her turn to read [aloud],' she said (writing in the third person), '[she]...would gaze on these maps until the shapes of the countries with their islands and inlets became photographed on her brain. Baffin Bay and the land around the poles were especially fascinating to her.' For some children, on the other hand, such shapes were deadening. Ethel Richardson (afterwards Henry Handel Richardson) remembered her own school days in Melbourne. 'She knew,' she said (also using the third person), 'from hearsay, just how England looked...its ever-green grass, thick hedges, and spreading trees; its never-dry 
rivers; its hoary old cathedrals; its fogs, and sea-mists, and over populous cities.' This hearsay had nothing to do with the unfamiliar diagram she confronted in geography lessons: a map of the mother country 'seared and scored with boundary-lines, black and bristling with names'. ${ }^{17}$ The trick lay in letting such shapes take on a many-layered but speechless imagery, as Flora Thomson did.

The profound way in which cartographic knowledge made its mark on contemporary imagination can be seen in an extraordinary book published in England in 1884, called Flatland: A Romance in Many Dimensions. The author, Edwin Abbott (writing as 'A Square'), was an Anglican theologian and schoolmaster. His story suggests a delight in geography and geometry. Thus, imagination struggles to comprehend worlds of different dimensions, from the one-dimensional to the four-dimensional and beyond. Flatland is remembered today partly as a precursor of computer graphics, or hypergraphics. ${ }^{18}$ Its message, however, bears directly on the rise of mass cartographic literacy. Maps, after all, like computer graphics, render the familiar three-dimensional world in counter-intuitive two dimensions.

Rolf Boldrewood gives a neat account of the uses of geography for the individual in a story published in 1888-89, called A Sydney-Side Saxon. The hero starts by telling of his origins in poverty in England. As a boy, he says, he had read Walter Scott's story Ivanhoe. His imagination had fixed on Scott's description of a Saxon serf wearing a brass collar inscribed with details of his bondage to one lord and one place. For the hero, freedom from a metaphorical collar-from poverty and powerlessness - depended on knowledge, especially knowledge of geography. People of his rank in England, he says, 'knew no more about Australia, or Canada, or New Zealand, than the man in the moon', yet '[a]ny man or woman that can read and write, keep simple accounts, and understand a map, has got hold of the levers that move the world'. '[I]t is his own fault,' he says, 'if he doesn't prise out a corner for himself somewhere.' 'I was sharp about geography,' he goes on, 'so I looked out Australia, and found that there were divisions or colonies with large cities and houses, just like other places.' He came to this country, where he was taken up by a helpful squatter and shown a map of surrounding runs. There, concealed among lines that only the initiated could properly understand, was a sliver of uncharted territory, about seven miles by five, waiting to be taken up. On it, the hero made his fortune. ${ }^{19}$

For the 'imagined community' of the nation, and even more, perhaps, for the imagined community of race, cartographic literacy was crucial. In late-nineteenth-century debates about race, the powerful charm of geography is certainly very obvious, with its talk of expanding and retreating races and of 'black belts' and 'yellow belts' encircling the globe. The argument in Charles Pearson's celebrated book National Life and Character, published in 1893 shortly after he returned to England after many years in Australia, depended on this 
clear-cut sense-primitive as it seems today-of the spatial dimensions of humanity. So did contemporary nationalism.

Two distinct approaches were used in teaching geography in colonial schools. J. J. Fletcher has suggested that one method was inductive and the other deductive. The first, he says, 'began with the child's immediate environment and gradually moved out from there to include the world as a whole'. The second 'began with a view of the world (or even the universe) and worked down to particular areas'. The latter was, however, not wholly deductive because it rarely reached as far as the local and immediate. ${ }^{20}$ In Victoria, where this top-down method prevailed until the late 1880s, the curriculum began in second class with ' $[t]$ he continents, oceans, and larger seas, with their relative positions', and the main point in third and fourth class was to add detail to this very large picture. In fifth class, there was a more particular focus, the work at that stage being described as '[m]aps of Europe and Australia'. Then in sixth class - the top class - the syllabus was as broad as could be: '[g]enerally of the world.' ${ }^{21}$

In South Australia, schools were required to use the inductive method. Teachers were told to concentrate to begin with on 'local geography'. This involved drawing spatial diagrams of the classroom, the school buildings and the neighbourhood and gathering knowledge of the surrounding landscape. When children had grasped the disciplinary method in this way they were shown maps on a larger scale and told of mountains, rivers and oceans, which they had never seen and could never hope to see, except in diagrammatic form. Inevitably in South Australia there was a strong emphasis on the colony and on the continent. In first class, children were taught '[c]ardinal points and local topography' and, in second class, they went on to '[t]he definitions of land and water and outlines of South Australia'. In third class, the curriculum was 'Australia in outline...South Australia in detail' and, in fourth class, '[o]f Europe... Ability to draw the maps of Australia and South Australia', while in fifth class, it was ' $[\mathrm{g}]$ enerally of the world' ${ }^{22}$ As an inspector remarked, the child was first told 'something about his own neighbourhood, the hills that surround it, the creeks which flow through it, the seas which wash its shores...[a method] leading his mind forward from the known to the unknown' ${ }^{23}$ The main challenge lay in making the leap between dimensions, and from the concrete to the abstract. As one of the inspector's colleagues remarked, the advance 'from the geography of the neighbourhood to that of all South Australia is a great stride'. Maps were the key, because cartographic literacy applied in the same way to all places-large and small. This inspector believed, for reasons he did not explain, that the leap outwards from Australasia to the world was the hardest of all. ${ }^{24}$

Through most of the 1870 s and 1880s, it was a prime goal for many inspectors - perhaps for them all-that children master the geography of the colony in which they lived. As James McCredie remarked in 1874, children 
ought to understand the physical characteristics of 'their own country' - and by that he meant New South Wales. ${ }^{25}$ His colleague in the same colony, J. H. Murray, reported in 1883, 'I have endeavoured to impress upon teachers the idea that Australian boys and girls of twelve or thirteen years of age should be as thoroughly acquainted with the geography of their own country as European girls and boys are with theirs.' In spite of what this statement might imply to start with, what Murray meant was that a child in New South Wales should learn about New South Wales just as, say, a French child learnt about France. ${ }^{26}$ In short, only 16 years before the referenda on Federation, geographical understanding was very different-among all ranks - from that on which Federation was to depend.

In geography, only towards the end of the 1880s do we find any interest in Australia for its own sake. In Victoria, the syllabus was changed at that point. As a result, according to an inspector, 'Victorian children are supposed to learn and to thoroughly know the leading features and the industrial resources of our own continent before they are taught much about the outside world'. ${ }^{27}$ Therefore, he suggested, '[m]aps of the colonies should be supplied to all schools in lieu of maps of Asia, Africa, and America' ${ }^{28}$ This notion of 'our own continent' set against 'the outside world' was, of course, the essence of continental nationalism (although it was not clear yet that 'our own continent' included Tasmania). In the following year, C. H. Pearson, now Victorian Minister of Public Instruction, called for books to meet what he described as 'the particular needs of Australian children'. ${ }^{29}$ The minister in New South Wales, J. H. Carruthers, agreed: 'To a large extent,' he said, 'the subject matter of the lessons should be Australian', or else it 'should be dealt with, as far as practicable, from points of view interesting to Australians' ${ }^{30}$ Such points of view must have been informed by the circumstances of daily life, wherever they seemed peculiar to the continent as a whole.

Inspectors were already beginning, very slowly, to make similar suggestions. In getting the children to read aloud and to memorise verse, said F. H. Rennick at St Arnaud in Victoria, in 1888, we should use 'our own Australian poetry'. 'Among the poems of Gordon and Kendall,' he said (and he later added Charles Harpur), 'we have specimens that breathe a true Australian spirit.' In our textbooks, for instance, information on 'Australian fauna and flora' ought to be mixed up with what he called 'gems of Australian song'. 31

This leads me back to the question of reading, or rather, of speech. When inspectors commented on expression in reading they also commented, very often, on pronunciation. Problems with pronunciation had always been understood as a narrowly colonial rather than a continent-wide phenomenon. Many inspectors were interested in the way in which English regional 
peculiarities made their impact here. In Melbourne, A. C. Curlewis remarked on the way in which Victorians of various ethnic origins dropped their ' $h$ 's:

From the Cockney and the Cornish the disease has spread to the Scotch and Irish. We [Victorians] are in a fair way of becoming a nation without an $\mathrm{h}$ in our vocabulary. From the average choir you will be pretty sure to hear "eaven' and "ell', and "oly, 'oly, 'oly'. The average porter shouts out "Awthorn' and "Awksburn', and the average cabman 'Emerald 'ill'. There are other weak points in Victorian pronunciation; but this, I think, is the worst. ${ }^{32}$

His colleague, James Holland, wrote in the same terms. '[T]he distinguishing characteristics of Victorian pronunciation,' he said, 'are a slight tendency to a nasal accent and a want of crispness and distinctness in enunciation.' The Aborigines, he suggested, did the same. ${ }^{33}$ It did not occur to him, apparently, in spite of his comparison with the Aborigines, that this might be a continental phenomenon. As with geography, knowledge of Victoria remained an end in itself. Issues of speech were anchored in Victorian society and Victorian space.

As with geography, however, ambiguities began to appear by the end of the period. Take the statement of Alfred Jackson, of Stawell, in 1890. 'Unless we have some decided improvement,' he said, 'the next generation must not be surprised if foreigners or neighbouring colonists are able to detect a Victorian rustic by his monotonous drawl.' On the one hand, Jackson divided non-Victorians into two categories: 'foreigners' and 'neighbouring colonists'. On the other hand, he still referred to common habits of speech in Victoria as if they were peculiar to that colony.

I have said that in South Australia the teaching of geography began with the local and moved by stages towards the global. The middle stage was the continent as a whole. This approach gave a kind of absolute value to the colony and the continent. In many ways, South Australians were always more willing than neighbouring colonists to see themselves as part of a community of provinces. They were more ready, for instance, than either Victorians or New South Welshmen to make formal and detailed comparisons between their school systems and those of their neighbours.

Similarly, in 1886, Alexander Clark, in South Australia, reported on his own district in such a way as to bring the continent automatically within his purview. 'Australians on the average,' he said, 'speak better English than the people of England themselves.' ${ }^{34}$ What did he mean by 'better'? Naturally, the inspectors thought of their own usage as the best standard, but they placed particular stress on the need for uniformity from place to place, as if the two criteria amounted to the same. Speech was to be undifferentiated in every corner of the continent (perhaps in every corner of the Empire). It was to be contingent on the truths 
of geography and explored and controlled with the help of maps. A three-dimensional phenomenon - a phenomenon of the most impulsive, intimate and palpable kind - was to exist as well in two dimensions, on paper. The inspectors seem, in short, to have been confused as to where varieties of accent came from. On the one hand, they condemned what they called 'vulgarisms' - as if accent were a matter of social rank. On the other hand, and much more often, they spoke of 'colonialisms' and 'provincialisms'. They linked pronunciation - good and bad-with place.

Here, said Clark, 'the school children of Brisbane, Sydney, Melbourne, and Adelaide are much more nearly allied in speech than those of London, Plymouth, Leeds, and Newcastle'. He seems to have used an assumption that nation-building - whatever the nation might be - involved the breaking down of regional and local boundaries, a process that necessarily involved the wearing away of regional and local accents, plus strenuous efforts to make sure that no new peculiarities emerged as new communities became established. He had no hope, apparently, of a kind of providential unfolding of the Australian, or even South Australian, national type. On the contrary, as settlement became established, he thought, provincial differences would open up here as well. Teachers must work hard, therefore, to establish a single standard. ${ }^{35}$ 'The Australias,' he said in 1888 (and by that he meant the various colonies of Australia), 'are at present devoid of the marked provincialisms of Yorkshire, Lancashire, or Somerset, and even of the less objectionable peculiarities of London or American speech.' 'Peculiarities' were, of course, the problem. ${ }^{36}$

Bad speech was a symptom of ignorance, of restricted horizons and of local attachment, when nation and empire were the true means of intelligent humanity. Bad speech was like the serf's brass collar in Ivanhoe - a token of bondage to be carried everywhere, binding its wearer to rank and place.

Here was a clear preference for continental nationalism, a belief in a continental type. Australia's imagined community was to be deduced from writing and from cartographic imagery and it was to be manifest in speech. Uniformity of speech was as telling, in other words, as uniformity of race. It might have been hard to agree on what that speech should be like. Leading writers of fiction-such as Henry Lawson, Joseph Furphy - might look to the language of the common man, to the vulgarisms condemned by inspectors. Their interest in the subject, no less vivid than the inspectors', shows that it was a matter of significant concern among a great variety of opinion-makers. Perhaps an interest in speech, as a symptom of national type, was unusually strong in this part of the world. Melvyn Bragg, in his account of the English language world-wide, remarks on Australians' distinctive 'love affair' with their own accent, beginning in these years. 'This was a people,' he says, 'finding its identity in the most essential and enjoyable 
way. $^{37}$ It was a tortured love affair, no doubt, but some Australians were clearly happy to be bound to a place both limited and vast.

All these late-nineteenth-century authorities might well have agreed on the purpose of reading: on the need to make each child an effective citizen, civilised and efficient in the use of his or her voice. The great aim was also to create a uniformity of sound - parallel with uniformity of race - within the circumference of the nation.

\section{ENDNOTES}

${ }^{1}$ Hirst, John 2000, The Sentimental Nation: The Making of the Australian Commonwealth, Melbourne.

2 Birrell, Bob 2001, Federation: The Secret Story, Sydney (earlier version published in 1995 as A Nation of Our Own), pp. 112-14.

3 Burgan, Thomas 1882, 'Inspector's report, 1 February 1882, Report of the Minister controlling Education, 1881', Proceedings of the Parliament of South Australia, vol. 3, no. 44, p. 15.

4 Burgan, Thomas 1877, 'Inspector's report, 23 January 1877, Report of the Minister controlling Education, 1876', Proceedings of the Parliament of South Australia, vol. 2, no. 34, p. 21.

5 Roche, D. M. 1889, 'Inspector's report, 6 June 1889, Report of the Minister of Public Instruction, 1888-89', Victorian Legislative Assembly Votes and Proceedings, vol. 4, no. 98, p. 167.

6 Hepburn, Thomas R. 1885, '9 April 1885, Report of the Minister of Public Instruction, 1884-85', Victorian Legislative Assembly Votes and Proceedings, vol. 4, no. 74, p. 151 (original emphasis).

7 Whitham, C. L. 1880, 'Inspector's report, February 1880, Report of the Minister controlling Education, 1879', Proceedings of the Parliament of South Australia, vol. 3, no. 44, p. 15.

8 George Snell (1649), quoted in Watson, Foster 1909, The Beginnings of the Teaching of Modern Subjects in England, London, pp. 40-1.

${ }^{9}$ Kevin, John 1883-84, 'Inspector's report, 11 January 1883, Report of the Minister of Public Instruction, 1882', NSW Legislative Assembly Votes and Proceedings, vol. 7, p. 718.

${ }^{10}$ McCredie, James 1870-71, 'Inspector's report, 23 February 1871, Report of the Council of Education, 1870', NSW Legislative Assembly Votes and Proceedings, vol. 4, p. 232.

11 Jones, J. S. 1870-71, 'Inspector's report, 13 February 1871, Report of the Council of Education, 1870', NSW Legislative Assembly Votes and Proceedings, vol. 4, p. 213.

12 Johnson, Edwin and James W. Allpass 1872, 'Inspectors' report, 25 January 1872, Report of the Council of Education, 1871', NSW Legislative Assembly Votes and Proceedings, vol. 2, p. 623; Hosking, James 1879, 'Inspector's report, n.d., Report of the Minister controlling Education, 1878', Proceedings of the Parliament of South Australia, vol. 3, no. 35, p. 22.

13 Pearson, Charles H. 1878, Report on the State of Public Education in Victoria and Suggestions as to the Best Means of Improving It, Melbourne, p. 61.

14 Lewis, Alexander T. 1882-83, 'Inspector's report, n.d., Report of the Minister of Public Instruction, 1881-82', Victorian Legislative Assembly Votes and Proceedings, vol. 3, no. 67, p. 215.

15 Phillips, Derek 1988, The State and the provision of education in Tasmania, 1839 to 1913, Ph.D. thesis, University of Tasmania, pp. 321-6; Jones, J. S. 1870-71, 'Inspector's report, 13 February 1871, Report of the Council of Education, 1870', NSW Legislative Assembly Votes and Proceedings, vol. 4, p. 213; Johnson, William R. 1994, "Chanting Choristers": Simultaneous recitation in Baltimore's nineteenth-century primary schools', History of Education Quarterly, vol. 34, pp. 14-16, 22.

16 Coote, Anne 2004, Space, time and sovereignty: Literate culture and colonial nationhood in New South Wales up to 1860, Ph.D. thesis, University of New England, pp. 132-51.

17 Thompson, Flora 1945, Lark Rise to Candleford, Oxford University Press, London, p. 174 (I owe this reference to David Kent); Richardson, Henry Handel 2001, The Getting of Wisdom, Clive Probyn and Bruce Steels (eds), University of Queensland Press, St Lucia, p. 66.

18 'A Square' [Edwin Abbott] 1884, Flatland: A Romance of Many Dimensions, Seely \& Co., London; Banchoff, Thomas H. 2005, From Flatland to Hypergraphics: Interacting with Higher Dimensions, available from www.geom.uiuc.edu/ banchoff/ISR/ISR.html (accessed 19 April 2005).

19 Boldrewood, Rolf 1925, A Sydney-Side Saxon, Sydney, pp. 12, 18, 32, 140-1. 
20 Fletcher, J. J. 1973, 'Teaching Geography in the National Schools of New South Wales 1848-1866', in S. Murray-Smith (ed.), Melbourne Studies in Education, Melbourne, p. 194.

21 'School curriculum, Ninth Report of the Board of Education, 1870', Victorian Legislative Assembly Votes and Proceedings, 1871, vol. 3, no. 33, p. 22.

22 'Standard of proficiency for scholars, Report of the Central Board of Education, 1873', Proceedings of the Parliament of South Australia, 1874, vol. 2, no. 24, p. 24

23 Jung, Emil 1875, 'Inspector's report, n.d., Report of the Central Board of Education, 1874', Proceedings of the Parliament of South Australia, vol. 2, p. 13.

24 Dewhirst, Edward 1877, 'Report of the Council of Education, 1876', Proceedings of the Parliament of South Australia, vol. 2, p. 11; Dewhirst, Edward 1880, '19 February 1881, Report of the Minister controlling Education, 1880', Proceedings of the Parliament of South Australia, vol. 3, no. 44, p. 4.

25 McCredie, J. 1873-74, 'Report of the Council of Education, 1873', NSW Legislative Assembly Votes and Proceedings, vol. 5, p. 328.

26 Murray, J. H. 1883-84, 'Inspector's report, 31 January 1883, Report of the Minister of Public Instruction, 1882', NSW Legislative Assembly Votes and Proceedings, vol. 7, p. 711.

27 Eddy, F. C. 1889, 'Inspector's report, 31 May 1889, Report of the Minister of Public Instruction, 1888-89', Victorian Legislative Assembly Votes and Proceedings, vol. 4, no. 98, p. 169.

28 Eddy, F. C. 1888, 'Inspector's report, May 1888, Report of the Minister of Public Instruction, 1887-88', Victorian Legislative Assembly Votes and Proceedings, vol. 3, no. 99, p. 168.

29 Pearson, Charles H. 1890, 'Report of the Minister of Public Instruction, 1889-90, 2 October 1890', Victorian Legislative Assembly Votes and Proceedings, vol. 3, no. 90, p. xxi.

30 Carruthers, J. H. 1891-92, 'Report of the Minister of Public Instruction, 9 April 1891', NSW Legislative Assembly Votes and Proceedings, vol. 3, pp. 42-3.

31 Rennick, F. H. 1888, 'Inspector's report, May 1888, Report of the Minister of Public Instruction, 1887-88', Victorian Legislative Assembly Votes and Proceedings, vol. 3, no. 99, p. 162; Rennick, F. H. 1890, 'Inspector's report, April 1890, Report of the Minister of Public Instruction, 1889-90', Victorian Legislative Assembly Votes and Proceedings, vol. 3, no. 90, p. 225.

32 Curlewis, A. C. 1885, 'Inspector's report, 18 April 1885, Report of the Minister of Public Instruction, 1884-85', Victorian Legislative Assembly Votes and Proceedings, vol. 4, no. 74, p. 134.

33 Holland, James 1887, 'Inspector's report, 30 May 1887, Report of the Minister of Public Instruction, 1886-87', Victorian Legislative Assembly Votes and Proceedings, vol. 3, no. 81, p. 142.

34 Clark, Alexander 1886, 'Inspector's report, 16 March 1886, Report of the Minister controlling Education, 1885', Proceedings of the Parliament of South Australia, vol. 2, no. 44, p. 15.

35 Ibid.

36 Clark, Alexander 1888, 'Inspector's report, February 1888, Report of the Minister controlling Education, 1887', Proceedings of the Parliament of South Australia, vol. 3, no. 44, p. 27.

37 Bragg, Melvyn 2003, The Adventure of English: The Biography of a Language, Hodder \& Stoughton, London, pp. 281-86. 